Research Report No. 25/2009

\title{
Reflections on U.S. Law Curricular Reform
}

Toni M. Fine

Follow this and additional works at: http://digitalcommons.osgoode.yorku.ca/clpe

\section{Recommended Citation}

Fine, Toni M., "Reflections on U.S. Law Curricular Reform" (2009). Comparative Research in Law \& Political Economy. Research Paper No. 25/2009.

http://digitalcommons.osgoode.yorku.ca/clpe/138 


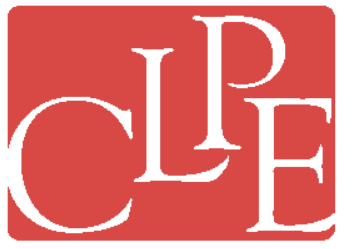

\section{Comparative Research in Law \& Political Economy}

\section{Toni M. Fine}

\section{Reflections on U.S. Law Curricular Reform}

EDITORS: Peer Zumbansen (Osgoode Hall Law School, Toronto, Director, Comparative Research in Law and Political Economy, York University), John W. Cioffi (University of California at Riverside), Nassim Nasser (Osgoode Hall Law School, Toronto, Production Editor)

Also available at: http://www.germanlawjournal.com 



\title{
German Law Journal
}

\author{
Reflections on U.S. Law Curricular Reform \\ Toni M. Fine
}

10 German Law Journal 717 (2009), available at:

http://www.germanlawjournal.com/article.php?id=1116 and

http://www.germanlawjournal.com/article.php?id=1117

This article was originally published in Volume 10, Number 7 of the German Law Journal as part of the journal's $10^{\text {th }}$ anniversary symposium on "Transnationalizing Legal Education" edited by Nadia Chiesa, Adam de Luca, and Bernadette Maheandiran. 
CLPE Research Paper 25/2009

Vol. 05 No. 04(2009)

Toni M. Fine

\title{
REFLECTIONS ON U.S. LAW CURRICULAR REFORM
}

\begin{abstract}
This paper explores recent - and somewhat less recent - critiques of U.S. legal education and ongoing curricular changes to U.S. legal education. It then explores some changes to U.S. legal education in recent years. Noting some of the institutional barriers to transformative changes to legal education, the articles discusses some of the most important modifications in recent years, including specialization, globalization, experiential learning, the integration of theory and practical skills, and teaching ethics and professionalism more pervasively. Although these (and other) changes are significant, legal education in the United States remains fundamentally much the same in many respects as it has been for the past century.
\end{abstract}

Keywords: Legal education, Curricular changes, U.S. Legal Education

JEL classification: K10, K40

Toni M. Fine

Assistant Dean for International and Non-J.D. Programs, Fordham Law School, New York City. Email:tfine@law.fordham.edu 



\title{
SPECIAL ISSUE: TRANSNATIONALIZING LEGAL EDUCATION
}

\section{Reflections on U.S. Law Curricular Reform}

\author{
By Toni M. Fine*
}

\section{A. Introduction}

There has not been dramatic reform to legal education for many years. Although changes to the way we train students to be lawyers certainly have been made in the past decades, there has not been occasion to fundamentally re-think the process for educating lawyers.

A recent report published by the Carnegie Foundation for the Advancement of Teaching ${ }^{1}$ and other critiques of the current state of legal education have re-energized discussions of curricular reform in law schools in the United States. Even as legal educators around the world struggle to adopt education reform - including in Europe where the Bologna Convention ${ }^{2}$ calls for what in some countries will be dramatic changes to legal education as usual, ${ }^{3}$ and in East Asia where Japan and Korea have recently undergone dramatic reforms to their method of legal education ${ }^{4}$-- U.S. law schools are being compelled to undergo serious rethinking about their curricular choices.

This paper explores critiques of U.S. legal education and ongoing curricular changes to U.S. legal education. Part I examines calls for changes to U.S. legal education. Part II discusses reforms that have been ongoing at law schools throughout the United States. Finally, this paper offers some modest conclusions about the future of U.S. legal education.

\footnotetext{
* Assistant Dean for International and Non-J.D. Programs, Fordham Law School, New York City. Email: tfine@law.fordham.edu.

${ }^{1}$ William M. Sullivan, Anne Colby, Judith Welch Wegner, Lloyd Bond, and Lee S. Shulman, Carnegie Foundation for the Advancement of Teaching, Educating lawyers: Preparation for the Profession of LaW (2007) (hereinafter “CARneGie Report").

2 Bologna Declaration of 19 June 1999, see http://ec.europa.eu/education/policies/educ/bologna/ bologna_en.html and http://www.ond.vlaanderen.be/hogeronderwijs/bologna/.

3 See, e.g., http://www.ond.vlaanderen.be/hogeronderwijs/bologna/, and http://www.unesco.org/iau/he/ bologna_process/ index.html, last accessed 16 June 2009.

${ }^{4}$ See, e.g., Setsuo Miyazawa, Kay-Wah Chan and Ilhyung Lee, The Reform of Legal Education in East Asia (December 23, 2008), Annual Review of Law \& Social Science, Vol. 4 (December 2008).
} 


\section{B. Calls for Reform of U.S. Legal Education}

Despite the predominance over the last century or so of the Landgell method of law teaching, there have been periodic calls for reform of legal education in the U.S. in the modern era, the most prominent of which will be discussed here. The first of these was a study released in 1979 commissioned by the American Bar Association (ABA), and known as the "Cramton Report". The second study, known as the "MacCrate Report," was a report released in 1992 by a task force formed by the ABA. Most recently, in 2007, the Carnegie Foundation for the Advancement of Teaching issued a report on the state of legal education in the United States and, in the same year, a volume of Best Practices was issued. The sections that follow discuss the findings and recommendations of these various reports and the response of the academe.

\section{The Cramton Report}

In 1979, the so-called Cramton Report, named for its primary author, was released. This report emphasized the importance of a law school curriculum which developed students' abilities in critical thinking and problem solving. ${ }^{5}$ Although the Cramton Report was perceived as a watershed in thinking about legal education and although it received a good deal of attention by the bar and among those in legal education, the recommendations contained in the Cramton Report ultimately were largely ignored. ${ }^{6}$

\section{The MacCrate Report}

The Report of the Task Force on Law Schools and the Profession: Narrowing the Gap, the so-called "MacCrate Report," was published in 1992. ${ }^{7}$ The mission and premises of the McCrate Report are so telling that it bears quoting from the report in some length:

While practicing lawyers undoubtedly appreciate the value of the law school experience to their own careers, surveys understandably indicate that practicing lawyers believe that their law school training left them deficient in skills that they were forced to acquire after graduation. Practitioners tend to view much academic scholarship as increasingly

\footnotetext{
${ }^{5}$ American bar Association Section of Legal Education and Admissions to the Bar, Report and Recommendations of the TASk Force on Lawyer Competency: The Role of the Law Schools (1979) (the “Cramton Report”).

${ }^{6}$ See, John J. Costonis, The MacCrate Report: Of Loaves. Fishes, and the Future of American Legal Education, 43 JOURNAL OF LEGAL EDUCATION 157 (1993).

${ }^{7}$ American Bar Association Section of Legal Education and Admissions to the Bar, Legal Education and Professional DeVelopment - An Educational ContinuUm: Report of the task Force on laW Schools and the PROfession: NARROWING THE GAP (1992) (the "MCCRATE REPORT"), available at http://www.abanet.org/legaled/publications/onlinepubs/ maccrate.html. Last accessed 16 June 2009.
} 
irrelevant to their day-to-day concerns, particularly when compared with the great treatises of an earlier era. It is not surprising that many practicing lawyers believe law professors are more interested in pursuing their own intellectual interests than in helping the legal profession address matters of important current concern.

Unquestionably, the most significant development in legal education in the post-World War II era has been the growth of the skills training curriculum. As recently as twenty years ago, the typical skills training component of a law school curriculum consisted of a first-year moot court program, and perhaps a trial advocacy course. Today, clinical courses, both in a simulated and live-client setting, occupy an important place in the curriculum of virtually all ABA-approved law schools. Many are taught by full-time faculty members who, pursuant to an ABA accreditation standard, are eligible for tenure or some form of equivalent job security. A clinician is present on virtually every $A B A$ site inspection team to help the team evaluate the quality of the law school's skills-training program, with particular emphasis placed on the commitment of resources and the availability of full-time faculty supervision when students are involved in externship forms of clinical programs.

Early in its deliberations this Task Force concluded that it was not possible to consider how to "bridge" or "narrow" the alleged "gap" between law schools and the practicing bar without first identifying the fundamental skills and values that every lawyer should acquire before assuming responsibility for the handling of a legal matter. Surprisingly, throughout the course of extensive decades-long debates about what law schools should do to educate students for the practice of law, there has been no in-depth study of the full range of skills and values that are necessary in order for a lawyer to assume the professional responsibility of handling a legal matter. Recognizing that such a study is the necessary predicate for determining the extent to which law schools and the practicing bar should assume responsibility for the development of these skills and values, the Task Force prepared a Statement of Fundamental Lawyering Skills and Professional Values. In Part II of the Report, the Task Force sets forth its view of the skills and values new lawyers should seek to acquire. ${ }^{8}$

The MacCrate Report thus identified and explored ten "fundamental lawyering skills essential for competent representation," including problem solving, legal analysis, legal research, factual investigation, communication, counseling, negotiation, litigation and

${ }^{8}$ Id. 
alternative dispute resolution, administrative skills, and recognizing and resolving ethical dilemmas. ${ }^{9}$ The MacCrate Report concluded with a number of recommendations: Disseminating and Discussing the Statement of Skills and Values, Choosing a Career in Law and a Law School, Enhancing Professional Development During the Law School Years, Placing the Transition and Licensing Process in the Education Continuum, Striving for Professional Excellence after Law School, and Establishing an American Institute for the Practice of Law. ${ }^{10}$ The MacCrate Report generated an enormous amount of discussion among members of the bar, the bench, and the legal academe, and is often credited with an increase in the number of clinical courses offered in U.S. law schools, but in the end did not yield any significant changes in legal education. ${ }^{11}$

\section{The Carnegie Report}

The Carnegie Report is one of a series that will include reports on educating clergy, engineers, nurses, and physicians. ${ }^{12}$ The Carnegie Report found that U.S. law schools are excellent at using the Socratic method to teach students to "think like lawyers." To draw on the language of the Carnegie Report website, the report "calls for fundamental changes in both the structure and content of legal education in the United States to integrate realistic and real-life lawyering experiences throughout the curriculum, and challenges American law schools to produce lawyers who are not only smart problem-solvers but also responsible professionals committed to service of both clients and the larger society." ${ }^{13}$

Despite accolades for certain aspects of U.S. legal education, the Carnegie Report was highly critical of U.S. law schools in a number of respects. Noting that that the legal profession suffers from "carrying degrees of confusion and demoralization," ${ }^{14}$ the report concluded that "[a] reawakening of professional élan must include revitalizing legal preparation." 15 The challenge for legal education, the authors found, is to do more to link

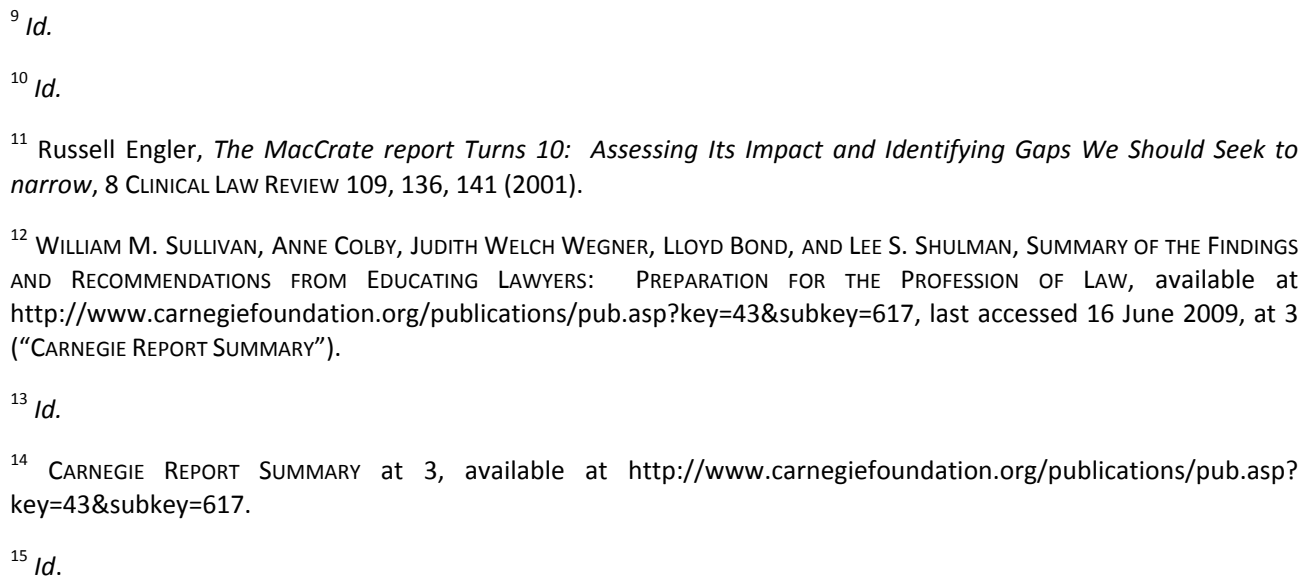


the "interests of legal educators with the needs of legal practitioners and with the public the profession is pledged to serve."

The Carnegie Report observed that the curriculum at most U.S. law schools follow a fairly standard pattern. ${ }^{17}$ Noting that law schools do a rather good job at teaching first year students the skills of legal analysis, the report bemoaned the lack of similarly effective efforts in other skills and professionalism training: "The dramatic results of the first years of law school's emphasis on well-honed skills of legal analysis should be matched by similarly strong skill in serving clients and a solid ethical grounding." 18

The Carnegie Report made five key observations, followed by a number of specific recommendations. The key observations were as follows:

Firstly, that law school provides rapid socialization into the standards of legal thinking. The Report looked favorably at the ways in which U.S. law schools socialize new students to the basics of legal analysis. As the report found:

Law schools are impressive educational institutions. In a relatively short period of time, they are able to impart a distinctive habit of thinking that forms the basis for their students' development as legal professionals. ... Within months of their arrival in law school, students demonstrate new capacities for understanding legal processes, for seeing both sides of legal arguments, for sifting through facts and precedents in search of the more plausible account, for using precise language, and for understanding the applications and conflicts of legal rules.... [T] hey are learning, in the parlance of legal education, to "think like a lawyer."19

Secondly, that law schools rely heavily on one way of teaching to accomplish the socialization process. According to the report, "[t]he process of enabling students to "think like a lawyer' takes places ... primarily through the medium of a single form of teaching: the case-dialogue method." The uniformity in legal pedagogy and the curriculum particularly in the first year - leads to "a striking conformity in outlook and habits of thought among legal graduates." ${ }^{20}$ The overwhelming priority given by most law schools to analytic thinking leads students "to understand the law as a formal and rational

\footnotetext{
${ }^{16}$ Id.

${ }^{17} / d$. at 4 .

${ }^{18} / d$.

${ }^{19}$ Id.at 5 .

${ }^{20} \mathrm{Id}$.
} 
system..... This emphasis on procedural and systematic gives a common tone to legal discourse." 21

Thirdly, that the case-dialogue method of teaching has valuable strengths but also unintended consequences. The report concluded that the case-dialogue method, long the mainstay of U.S. legal education, offers a "deliberate simplification" of central aspects of legal competence." 22 In this way, students learn to "think like a lawyer" simply by "redefining messy situations of actual or potential conflict as opportunities for advancing a client's cause through legal argument before a judge or through negotiation.... By contrast, the task of connecting these conclusions with the rich complexity of actual situations that involve full-dimensional people, let alone the job of thinking through the social consequences or ethical aspects of the conclusions, remains outside the case-dialogue method." ${ }^{23}$ Students often are "warned not to let their moral concerns or compassion for the people in the cases they discuss cloud their legal analysis." ${ }^{24}$ In introducing moral concerns in the curriculum "only haphazardly conveys a cynical impression of the law that is rarely intended." 25

In this respect, the Carnegie Report identified two major limitations of modern U.S. legal education. First, law schools typically pay "only casual attention to teaching students how to use legal thinking in the complexity of legal practice," with little attention given to "direct training in professional practice. The result is to prolong and reinforce the habits of thinking like a student rather than an apprentice practitioner, conveying the impression that lawyers are more like competitive scholars than attorneys engaged with the problems of clients." ${ }^{26}$ Second, the report found that law schools fail to provide "effective support for developing ethical and social skills.... [L]aw schools rarely pay consistent attention to the social and cultural contexts of legal institutions and the varied forms of legal practice. To engage the moral imagination of students as they move toward professional practice, seminaries and medical, business and engineering schools employ well-elaborated case studies of professional work" which are lacking in law schools. ${ }^{27}$ Both of these limitations, the report found, are the "unintended consequence of reliance upon a single, heavily

\footnotetext{
${ }^{21}$ Id.

${ }^{22} / d$.

${ }^{23}$ Id. at 6.

${ }^{24}$ Id.

${ }^{25}$ Id.

${ }^{26} / d$.

${ }^{27}$ Id.
} 
academic pedagogy, the case-dialogue method, to provide the crucial initiation into legal education." ${ }^{28}$

Fourthly, that assessment of student learning remains underdeveloped. The Carnegie Report argues that while most U.S. law schools do a reasonable job of conducting "summative assessment" they do far less well in terms of "formative assessment." "Summative assessment" relates to "supporting students in learning rather than ranking, sorting and filtering them....Formative assessments directed toward improved learning ought to be a primary form of assessment in legal education."29

Fifthly, that legal education approaches improvement incrementally, not comprehensively. The report noted that although U.S. law schools provide substantially more opportunities for experiential learning opportunities and more inter-disciplinary choices than they did fifty years ago, "efforts to improve legal education have been more piecemeal than comprehensive." ${ }^{30}$ "Rather than undertaking systematic or integrative reform efforts, U.S. law schools have assumed an additive strategy of educational change [which] assumes that increasing emphasis on the practical and ethical-social skills of the profession will reduce time for and ultimately affect the extent to which students develop skills in legal analyses.... This is not only a logistical problem (too much to accomplish in a limited amount of time) but it is also a conceptual and pedagogical problem." ${ }^{31}$

The report noted the need for "a dynamic curriculum that moves them back and forth between understanding and enactment, experience and analysis," that "bridge[s] the gap between analytical and practical knowledge," and that offers "more robust" opportunities for developing professional integrity, ${ }^{32}$ including "capacity for judgment guided by a sense of professional responsibility." ${ }^{33}$

In view of these findings, the Carnegie Report made the following seven recommendations:

${ }^{28} / d$.
${ }^{29} / d$. at 7.
${ }^{30} / d$.
${ }^{31} / d$.
${ }^{32} / d$.
${ }^{33} I d$.


1. Offer an Integrated Curriculum. Law schools should offer an integrated curriculum that (1) teaches legal doctrine and analysis; (2) introduces several facets of practice included under the rubric of lawyering; and (3) explores the "identity, values, and dispositions consonant with the fundamental purposes of the legal profession.".34

2. Join "Lawyering," Professionalism, and Legal Analysis from the Start. Law schools should provide students with "substantial experience with practice as well as opportunities to wrestle with the issues of professionalism.... The teaching of legal doctrine needs to be fully integrated into the curriculum. It should extend beyond case - dialogue courses to become part of learning to 'think like a lawyer' in practice settings. ${ }^{135}$ These other skills should be taught early in the curriculum. ${ }^{36}$

3. Make Better Use of the Second and Third Years of Law School. The third year of law school should be designed as a "capstone" opportunity "for students to develop specialized knowledge, engage in advanced clinical training, and work with faculty in serous, comprehensive reflection on their educational experience and their strategies for career and future professional growth." ${ }^{37}$

4. Support Faculty to Work Across the Curriculum. "Faculty development programs that consciously aim to increase the faculty's mutual understanding of each other's work are likely to improve students' efforts to make integrated sense of their developing legal competence." There should be a "sustained dialogue among faculty with different strengths and interests united around common educational purpose. ${ }^{38}$

5. Design the Program so that Students - and Faculty - Weave Together Different Kinds of Knowledge and Skill. Law schools must do better to demonstrate "how fully ethical-social issues pervade doctrinal and lawyering curricula" and provide "educational experiences directly concerned with the values and situation of the law and the legal profession." ${ }^{39}$

6. Recognize a Common Purpose. Noting that "the formation of competent and committed professionals deserves and needs to be the common, unifying

\footnotetext{
${ }^{34}$ Id. at 8

${ }^{35}$ Id.

${ }^{36} / d$.

${ }^{37}$ Id. at 9

${ }^{38}$ Id.

${ }^{39}$ Id.
} 
purpose," a greater focus on professionalism "would give renewed prominence to the ideals and commitments that have historically defined the legal profession in America., ${ }^{40}$

7. Work Together, Within and Across Institutions. The report reinforces the need to integrate different aspects of the law curriculum, noting that "integration can flourish only if law schools can consciously organize their emphases through ongoing mutual discussion and learning." ${ }^{41}$

The Carnegie Report findings and recommendations received a good deal of attention among legal educators, and has been the major focus of major sessions at the Annual Meeting of the Association of American Law Schools over a number of years. ${ }^{42}$

\section{Best Practices for Legal Education}

Close in time to the issuance of the Carnegie Report, Best Practices for Legal Education was published. ${ }^{43}$ Best Practices began with the fundamental observation that there is a "compelling need to change legal education in the United States in significant ways," noting that U.S. "[I]aw schools do some things well, but they do some things poorly or not at all." ${ }^{45}$ In particular, they are "not committed to preparing students for practice." ${ }^{46}$ The authors concluded that "II]aw schools can do much better."

Best Practices proposed seven ways in which law schools can develop best practices to enable them to better prepare students. These are: Setting Goals (Chapter Two), Organizing the Program of Instruction (Chapter Three), Delivering Instruction (Chapter Four), Conducting Experiential Courses (Chapter Five), Employing Non-Experiential Methods of Instruction (Chapter Six), Assessing Student Learning (Chapter Seven), and Evaluating the Success of the Program of Instruction (Chapter Eight). In short, the authors

\footnotetext{
${ }^{40}$ Id. at 10.

${ }^{41}$ Id.

${ }^{42}$ See, e.g., http://www.aals.org/am2000/4170.html, http://www.aals.org/am2008/location.html. Last accessed 16 June 2009. See also http://www.aals.org/profdev/newideas/why.html. Last accessed 16 June 2009.

43 Roy Stuckey and Others, BeSt Practices for Legal Education (2007), available at http://cleaweb.org/ resources/bp.html. Last accessed 16 June 2009.

${ }^{44}$ Id. at 19.

${ }^{45} / d$.

${ }^{46}$ Id.

${ }^{47}$ Id.
} 
"call on law schools to make a commitment to improve the preparation of their students for practice, clarify and expand their educational objectives, improve and diversify methods for delivering instruction, and give more attention to evaluating the success of their programs of instruction. ${ }^{48}$ Of particular note, the Report urged law schools to "organize their curriculums to develop knowledge, skills, and values progressively; integrate the teaching of theory, doctrine, and practice; and teach professionalism pervasively throughout all three years of law school., ${ }^{49}$

\section{Other Critiques}

The criticisms of U.S. legal education noted above are neither new nor novel. A number of legal educators over the years have noted the shortcomings of traditional methods of legal education in the U.S. As one author noted some years ago, the required curriculum "at many, if not most American law school virtually ignores at least half of the fundamental skills every lawyer should have." ${ }^{\prime 50}$ More recently, Stanford Law School Dean Larry Kramer said this:

[T]hinking like a lawyer is not the only skill necessary to be a great lawyer. Far from it. Knowing how to analyze helps lawyers help clients identify legal problems and avoid liability or secure a remedy when problems occur. But it doesn't help lawyers help clients solve problems the lawyers have spotted. To do that, you need also to understand what the client does.... [W] hen the client turns and asks the lawyer to help figure out a legal way to do [a] deal, the lawyer will need to know more than just doctrine. The lawyer will need to understand how the deal works, will need to know how to evaluate the risks and benefits, and will need to be able to work with the client to find a solution. ${ }^{51}$

\footnotetext{
${ }^{48} I d$.

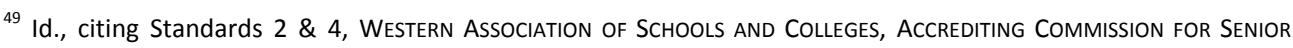
COlLEGES AND UNIVERSITIES, HANDBOOK OF ACCREDITATION (2001), available at http://www.wascsenior.org/ findit/files/forms/Handbook_of_Accreditation_2008_with_hyperlinks.pdf. Last accessed 16 June 2009. Roy Stuckey elsewhere presents twelve key recommendations for law schools. See http://bestpracticeslegaled. albanylawblogs.org/events-presentations-2/best-practices-powerpoint-materials/. Last accessed 16 June 2009.

${ }^{50}$ The required curriculum "at many, if not most, American law schools virtually ignores at least half of the fundamental skills every lawyer should have." John M. Burman, Oral Examinations as a Method of Evaluating Law Students, 51 JouRnAL Of LeGAL EduCATION 130, 132 (2001).

${ }^{51}$ Memorandum from larry Kramer, Richard E. Lang Professor of Law and Dean, Stanford Law School, to Members OF BOARD OF TRUSTEES, 12 February 2007, regarding Developments at the Law School, at 4, available at http://www.aals.org/services_curriculum_committee_innovations.php. Last accessed 16 June 2009.
} 
The case for an alternative type of experience during the third year of law school is also not new. ${ }^{52}$ The American Bar Association (ABA), the body that accredits law schools and programs of legal education in the United States, has also recognized the need for greater practical experience as an integral part of U.S. legal education. For instance, the ABA rules state as follows:

(a) A law school shall require that each student receive substantial instruction in:

(1) the substantive law generally regarded as necessary to effective and responsible participation in the legal profession;

(2) legal analysis and reasoning, legal research, problem solving, and oral communication;

(3) writing in a legal context, including at least one rigorous writing experience in the first year and at least one additional rigorous writing experience after the first year;

(4) other professional skills generally regarded as necessary for effective and responsible participation in the legal profession; and

(5) the history, goals, structure, values, rules, and responsibilities of the legal profession and its members. ${ }^{53}$

Section 302 (a) (4) of the ABA rules provide that law schools are to require that each student has "substantial instruction in . . . professional skills generally regarded as necessary for effective and responsible participation in the legal profession." ${ }^{154}$ Section 302(b) (1) provides that a law school offers substantial opportunities for "live-client or other real-life practice experiences, appropriately supervised and designed to encourage reflection by students on their experiences and on the values and responsibilities of the legal profession, and the development of one's ability to assess his or her performance and level of competence." ${ }^{55}$

\footnotetext{
52 See, e.g., Christopher T. Cunniffe, The Case for the Alternative third-Year Program, 61 ALBANY LAW REVIEW 85 (1997).

${ }^{53}$ ABA Sec. Leg. Educ. \& Admis. to the Bar, Standards for Approval of LAw Schools Stand. 302(a), 19-20 (ABA 2007) (available at http://www.abanet.org/legaled/standards/20072008StandardsWebContent/Chapter\%203.pdf). Last accessed 16 June 2009.

${ }^{54}$ Id.

${ }^{55}$ Id.
} 


\section{U.S. Legal Education Reform}

Legal Education in the United States remains very similar to legal education 100 years ago. The fundamental premises underlying how we go about training lawyers have remained largely intact. The program of study at most schools retains the same three-year structure ${ }^{56}$ with the first year comprised largely of required core doctrinal courses and a basic skills course. ${ }^{57}$ The second and third years at most law schools remain largely unstructured experiences during which students complete any required courses and choose from a range of electives. Although the nature of these electives has changed over time and now includes more clinics and other courses of an experiential nature, as well as more courses on global and transnational law, the basic foundation of the traditional second and years of law school remains much the same as they were for most of the twentieth century. Section 1 of this Part will explore some of the institutional barriers to more transformative changes to U.S. legal education.

Nevertheless, as suggested above, recent years have seen significant changes in legal education, largely as a result of the various critiques lodged against the status quo. Although change has taken many forms, the following categories of curricular modifications are particular noteworthy: (1) specialization; (2) experiential learning; (3) globalization; (4) integration of skills-based and doctrinal learning; (5) greater training in professionalism; and (6) enhanced feedback. Some of these categories track the critiques lodged in the Carnegie Report and other recent studies on U.S. legal education. These changes are discussed in part 2., infra.

\section{Changes to but No Major Transformation in U.S. Legal Education}

Legal education remains much the same as it did for the duration of the 1900 s. $^{58}$ As John Sexton said in his critique of the "remarkable conservatism"59 of U.S. legal education:

\footnotetext{
${ }^{56}$ Some law schools have begun to experiment with accelerated programs that allow students to complete the J.D. degree in fewer than three calendar years. For instance, Northwestern recently began accelerated two-year JD program for students with significant work experience prior to law school. See http://www.law.northwestern.edu/academics/ajd/. Last accessed 16 June 2009.

${ }^{57}$ A number of schools have begun to offer an advanced course or elective in the first year, as well as enhanced training in skills and professionalism. See Part D II., infra.

${ }^{58}$ See, e.g., Erwin Chemerinsky, Rethinking Legal Education, 43 HARVARD CIVIL RIGHTS - CIVIL LIBERTIES LAW REVIEW 595, 595 (208) ("legal education has changed remarkably little in over a century"); Keith A. Findley, Rediscovering the Lawyer School: Curriculum Reform in Wisconsin, 24 WISCONSIN INTERNATIONAL LAW JOURNAL 295, 300-01 (2006); John Lande, Developing Better Lawyers and Lawyering Practices: Introduction to the Symposium on Innovative Lawyering, 2008 JOURNAL OF DISPUTE RESOLUTION 1, 1.

59 John E. Sexton, "Out of the Box" Thinking about the Training of Lawyers in the Next Millennium, 33 UNIVERSITY OF TOLEDo LAW REVIEW 189, 194 (2001).
} 
What is surprising is that, in the face of seismic changes in the world of law practice, it has taken so long for the conversation [abut reforming U.S. legal education] to begin - and that our pedagogy has remained unchanged for over 100 years. True, the last three decades have seen the development of clinical legal education and interdisciplinary work; but these pedagogies have matured within the traditional framework, with the actual change being at the margins. 60

This "conservatism" in U.S. legal education may be explained by any number of reasons, including that despite the onslaught of criticism, legal education in the United States seems to have worked fairly well. In short, it may be that, despite legitimate critiques, there has not been motivation on the part of legal educations to undertake radical transformation of the way they have been doing business, rather successfully, for more than 100 years.

\section{Institutional obstacles to reform}

There are also a number of deeply entrenched institutional obstacles to reform. These include faculty attitudes, law school rankings, financial issues, disagreement as to the nature of legal education, and simple resistance to change based on momentum.

\section{a) Faculty attitudes}

There are a number of respects in which faculty attitudes foretell resistance to substantial changes in legal education: There is the reluctance to change in and of itself, and change is particularly challenging for some conventional faculty members when it comes to teaching experientially. It has been noted that law professors "may resist change because they prefer to replicate the environment in which they achieved success." 61 This may well be especially true when a proposed change involves the prospect of teaching skills or other experiential-based training. Law professors are hired for reasons that have absolutely nothing to do with law firm or other practical experience, ${ }^{62}$ and many law professors have little or no practice experience. ${ }^{63}$ Reluctance to support curricular reform may in fact

\footnotetext{
${ }^{60} / d$.

${ }^{61}$ John O. Sonsteng, Donna Ward, Colleen Bruce, \& Michael Petersen, A Legal Education Renaissance: A Practical Approach for the Twenty-First Century, 34 WILLIAM MITCHELL LAW REVIEW 303, 352 (2007) (noting that, in general, "law school professors were high achievers in law school.").

62 Requirements for tenure-track positions include "superior academic grades from top rank law schools, law review experience, prestigious judicial clerkships, [and] scholarly publications." Vernellia R. Randall, Increasing Retention and Improving Performance: Practical Advice on Using Cooperative Learning in Law Schools, 16 THOMAS M. COOLEY LAW REVIEW 201, 208 (1999).

63 Linda S. Anderson, Incorporating Adult Learning Theory into Law School Classrooms: Small Steps Leading to Large Results, 5 APPALACHIAN LAW JOURNAL 127, 134 (2006).
} 
reveal some discomfort with curricular modifications that may make certain faculty members feel a lack of confidence in their ability to take part in new, more modern visions of law teaching.

Second, many traditional doctrinal law faculty members view skills training as less important and less prestigious than the teaching of traditional doctrinal subjects. ${ }^{64}$ This may well dissuade faculty members from taking seriously calls for reform that embrace skills as a greater part of legal education or as more integral to doctrinal legal teaching.

Finally, and as a related matter, the legal academe generally places a substantially higher value on scholarship than it does on teaching. ${ }^{65}$ This reality suggests that many faculty members may not take legal education reform seriously or spend the necessary time to consider substantial curricular reform.

\section{b) The rankings game}

Another roadblock to serious undertakings to reform legal education may be concerns over how dramatic curricular changes may affect law school U.S. News \& World Report rankings. Although these rankings are highly criticized by deans and others within legal education, ${ }^{66}$ they are said to be a critical factor in the way that prospective students, faculty candidates, and law firm hiring committees evaluate law schools. ${ }^{67}$ There is also evidence to suggest that concern over rankings may, in fact, retard innovation in law schools. ${ }^{68}$

\footnotetext{
${ }^{64}$ See Deborah Jones Merritt \& Barbara F. Reskin, Sex, Race, and Credentials: The Truth about Affirmative Acton and Law Faculty Hiring, 97 ColumBIA LAW REVIEW 199, 261 (1997).

${ }^{65}$ See James Lindgren \& Allison Nagelberg, Are Scholars Better Teachers?, 73 CHICAGO-KENT LAW REVIEW 823, 82729; Deborah Jones Merritt, Research and Teaching on Law Faculties: An Empirical Exploration, 73 CHI.-KENT L. REV. 765, 807 (1998); Fred R. Shapiro, They Published, Not Perished, But Were They Good Teachers?, 73 CHI.-KENT L. REV. 835, 839 (1998); William R. Trail \& William D. Underwood, The Decline of Professional Legal Training and a Proposal for Revitalization in Professional Law Schools, 48 BAYLOR LAW REVIEW 201, 213 (1996).

${ }^{66}$ See, e.g., Louis H. Pollak, Why Trying to Rank Law Schools Numerically is a Non-Productive Undertaking: An Article on the U.S. News \& World Report 2009 List of "The Top 100 Schools," 1 Drexel LaW ReVIeW 52; Alex M. Johnson, Jr., The Destruction of the Holistic Approach to Admissions: The Pernicious Effects of Rankings, 81 INDIANA LAW JouRnAL 309 (2006); Rachel F. Moran, Of Rankings and Regulation: Are the U.S. News \& World Report Rankings Really a Subversive Force in Legal Education, 81 IND. L.J. 383 (2006); Brian Leiter, How to Rank Law Schools, 81 IND. L.J. 47 (2006).

${ }^{67}$ See N. William Hines, Ten Manor Changes in Legal Education Over the Past 25 Years, AALS NEWS at 2-3 (Aug. 2005), available at http://www.aals.org/documents/aals_newsletter_aug05.pdf. Last accessed 16 June 2009; See Andrew P. Morriss and William D. Henderson, Measuring Outcomes: Post-Graduation Measures of Success in the U.S. News \& World Report Law School Rankings, 83 IND. L.J. 791, 791 (2008); Theodore P. Seto, Understanding the U.S. news Law School Rankings, 60 SMU LAW REVIEW 493, 520 (2007).

${ }^{68}$ The AmERICAN BAR AsSOCIATION StANDARDS FOR THE APPROVAL OF LAW SCHOols have been said to have a similar effect.
} 
c) Cost

To the extent that calls for reform in U.S. legal education focus on experiential learning cost may play a significant role. It is no secret that skills courses and clinics are substantially more expensive to run than are traditional lecture-based courses, ${ }^{69}$ a reality that may drive curricular reforms.

d) Tension between Law as Craft or Law as Field of Serious Intellectual Inquiry

Part of the difficulty in achieving substantial curricular reform, it may be, is the uncertainty over whether law is more of a trade for which one needs a technical qualification or a rigorous fields of intellectual inquiry. ${ }^{70}$ Consider these two very different notions of law. First, a statement by Christopher Colombus Langdell, who in 1887 said as follows:

[L]aw is science, and ... all the available materials of that science are contained in printed books .... We have also constantly inculcated the idea that the library is the proper workshop of law professors and students alike; that it is to us all that the laboratories of the university are to the chemists and physicists, the museum of natural history to the zoologists, the botanical garden to the botanists. ${ }^{71}$

Some fifty years later, Jerome Frank had this to say, in sharp disagreement with Langdell's ideas about legal education:

Students trained under the Landgell system are like future horticulturists confining their studies to cut flowers, like architects who study pictures of buildings and nothing else. They resemble prospective dog breeders who never see anything but stuffed dogs. And it is beginning to be suspected that there is some correlation between that kind of stuffed-dog study and the over-production of stuffed shirts in the legal profession. ${ }^{72}$

\footnotetext{
${ }^{69}$ See, e.g., Ann Juergens, Using the MacCrate Report to Strengthen Live-Client Clinics, 1 CLINICAL LAW ReVIEW 411, 414 (1994). See also CARNEGIE REPORT SUMMARY at 10.

${ }^{70}$ See Simon Chesterman, The Globalisation of Legal Education, 2008 SINGAPORE JOURNAL LEGAL STUdieS, 58, 59.

${ }^{71}$ Christopher Columbus Langdell, The Harvard Law School, 3 LAW Quarterly ReVIEW 123, 124 (1887), quoted in Simon Chesterman, The Globalisation of Legal Education, 2008 SING. J.L.S. 58, 58.

72 Jerome Frank, Why not a Clinical Lawyer-School?, 81 U. Pa. L. Rev. 907, 912 (1932), quoted in Simon Chesterman, The Globalisation of Legal Education, 2008 SING. J.L.S. 58, 58.
} 
It may well be that some of the challenges in reforming legal education comes from a bona fide disagreement as to which of the approaches exemplified by these very different viewpoints is more legitimate today.

e) Momentum

Finally, reluctance to undertake legal education reform may be a simple product of momentum. As one author described it, "we carry the current paradigm of law school teaching on through sheer momentum; while, like the emperor without clothes, we persist in pretending that all is well." ${ }^{73}$ The truth is that, notwithstanding well-placed criticism of U.S. legal education, the modern paradigm has served the profession reasonably well.

\section{Changes to Modern U.S. Legal Education}

Keeping in mind the reasons that make major reform to legal education in the United States difficult, law schools in recent years have undertaken notable reforms and a few schools have undergone substantial changes. Modifications have been in a number of areas as detailed below: Specialization; globalization; experiential learning; greater integration of theory and practical skills; teaching professionalism and ethics more pervasively (and experientially); and providing more meaningful feedback to students. Some modest efforts have been made to "teach the teachers" by providing for a sharing of ideas and best practices with regard to teaching strategies. Each of these forms of innovation is discussed below, giving examples of the many innovations undertaken by U.S. law schools in recent years.

\section{a) Specialization}

One of the driving forces in legal education in recent years has been a move toward increasing specialization. Not long ago, students took a range of courses that spanned doctrinal areas, often with little meaningful attention paid to developing proficiency in any substantive area. More recently, law schools have begun to appreciate the value to students (and to the bar) of encouraging and promoting student specialization in one or more fields.

In a number of law schools, this focus on specialization has been accomplished though tracks or concentrations (sometimes accompanied by certificates) within the upper level J.D. curriculum. The University of Minnesota, for instance, offers J.D. concentrations in Health Law and Bioethics, Human Right, and Labor and Employment. ${ }^{74}$ Northwestern's

\footnotetext{
${ }^{73}$ Vernellia R. Randall, Increasing Retention and Improving Performance: Practical Advice on Using Cooperative Learning in Law Schools, 16 THOMAS M. COOLEY LAW REVIEW 201, 209 (1999).

${ }^{74}$ See http://www.law.umn.edu/current/concentrations.html. Last accessed 16 June 2009.
} 
Plan 2008 calls for the establishment of tracks for student course selection in the third year. $^{75}$ Other law schools offer specialized tracks or concentrations in international law, business law, criminal law and procedure, social justice, public law, transnational law, environmental law, real estate law, intellectual property, family law, elder law, and alternative dispute resolution. ${ }^{76}$

Capstone and keystone courses are another way in which law schools are attempting to allow students to achieve some degree of specialization. ${ }^{77}$ For instance, keystone courses are offered at William Mitchell law school ${ }^{78}$ and capstone courses are offered at the University of Minnesota,79 Southwestern Law School, ${ }^{80}$ and at University of Washington Law School, which offers a series of legal research and writing capstone courses. ${ }^{81}$

The movement toward specialization begins early in some law schools. Some law schools have added an elective to the first year curriculum, ${ }^{82}$ and a larger number of law schools have included non-traditional substantive courses as part of the required first year program. $^{83}$ These include courses on evidence, criminal procedure, regulatory law,

75 See PLAN 2008: PREPARING GREAT LEADERS FOR THE CHANGING WORLD, http://www.law.northwestern.edu/difference/ strategicplan.html, at 17. Last accessed 16 June 2009.

76 See AALS COMmittee ON Curriculum Survey of INNOVAtions in LAW SCHOOL CURricula, http://www.aals.org/services_curriculum_committee_survey.php at 16-20 ("AALS Survey"). Last accessed 16 June 2009.

${ }^{77}$ The difference between capstone and keystone courses has been described by one professor as follows: "A keystone sits at the top of an arch and holds all the other stones in place. Unlike the more familiar "capstone course" - which takes ots name from the stone at the top of a wall - a Keystone Course represents both a pinnacle and a passage. A Keystone Courses is a transformational learning experience representing both the culmination of law school learning and a transition to law practice and a lifetime of self-directed learning.' DENISE ROY, PATHWAYS at 66.

${ }^{78}$ Id.

79 "The Capstone courses are being designed to provide students with intensive immersion in a particular doctrinal area through collaborative or multidisciplinary work on a complex problem." These courses include classroom components and experiential components. Id. at 90.

80 "Capstone Courses provide the opportunity for advanced study, with special emphasis on teaching the Carnegie Foundation Report principles of theory to practice and professionalism. A given Capstone can be interdisciplinary, cover multiple subjects, and be team-taught." Id. at 95.

${ }^{81}$ Capstone courses are designed to integrate "information-based knowledge and skills-based knowledge into a unified whole." Id. at 22.

${ }^{82}$ See AALS SURVEY at 2.

${ }^{83}$ See AALS SURVEY at 9-10. 
international law, and legal theory. ${ }^{84}$ The shift toward specialization in U.S. law schools is also obvious in the increasing variation among law school clinics. ${ }^{85}$

A substantial number of U.S. law schools now offer joint degree programs that allow J.D. students to also complete a master degree in disciplines ranging from business administration, international affairs/international relations, and public administration to degrees in library science, social work, divinity, industrial engineering, and historic preservation. ${ }^{86}$ Fordham Law School offers dual degree programs with the university's School of Graduate Business Administration and the School of Social Work. ${ }^{87}$

b) Globalization

A second emerging trend in U.S. legal education over the past 15 years or so is that toward globalization. The movement toward globalizing legal education has taken a variety of forms, including curricular reform, an internationalization of faculty members and the student body, and a rise in extracurricular programs involving global legal issues.

NYU School of Law, through its Hauser Global law School Program is recognized by many as one of the premier global programs among U.S. law schools. NYU describes its commitment to globalization as more than "a catchword limited to adding courses to cover 'hot' international topics or to respond to passing demands for relevance. It is a fundamental organizing principle." ${ }^{88}$ NYU's global program reflects the Law School 's conviction that the practice of law has escaped the bounds of any particular jurisdiction and that legal education can no longer ignore the interpenetration of legal systems. Since its inception in 1994, the HGLSP has overseen a radical change in the structure of NYU Law faculty and curriculum, the composition of the student body, and the range of extracurricular opportunities. The goal has been to transform legal education and make NYU Law a "global" rather than merely a national law school. ${ }^{89}$

Northwestern Law School, another leader in the trend toward globalization, has recently re-affirmed its recognition that law graduates should possess "cross-jurisdictional ability" "an understanding of the basic policy choices that a specific legal system can make to

\footnotetext{
${ }^{84}$ Id.

${ }^{85}$ See AALS SURVEY at 21-24. See also Becky L. Jacobs, A Lexical Examination and (Unscientific) Survey of Expanded Clinical Experiences in U.S. Law Schools, 75 TeNNESSEE LAW REVIEW 343, 354-55 (2008).

${ }^{86}$ See AALS SURVEY, passim.

${ }^{87}$ See http://law.fordham.edu/ihtml/cur-2dualdegree.ihtml?id=435. Last accessed 16 June 2009.

${ }^{88}$ See http://www.law.nyu.edu/global/index.htm. Last accessed 16 June 2009.

${ }^{89} / d$.
} 
resolve economic and personal projects and conflicts that clients have throughout the world... [The ability] to operate and manage cross-border transactions and dispute resolutions effectively." ${ }^{\prime \prime 0}$ In addition, students must possess "cross-cultural sensitivity" and the ability to work effectively on teams with people from different cultures. ${ }^{91}$ Northwestern thus recommends preparing students to function effectively in cross-border contexts by integrating JD/LLM students on teams, offering non-US internships, and developing projects that provide substantial interactive and collaborative cross-cultural experiences. $^{92}$

There are a number of ways in which U.S. law schools have been globalizing through curricular reform. These include the broadening and deepening of curricular choices in "global" courses in both the upper level and in the first year, as well as enhanced study abroad opportunities, including joint and dual degree programs with foreign institutions.

The number and scope of courses in international, comparative, and foreign law has increased exponentially in the past years, and these courses are being offered at more and more law schools. Such courses include the more basic offerings in international law, comparative law, International trade law, international business transactions, EU law, and international arbitration; but offerings also now include far more highly specialized courses. ${ }^{93}$ Some schools have announced specific efforts to enrich the law curriculum in areas of international law. ${ }^{94}$ A number of U.S. law schools now offer concentrations or certificates in transnational law. Yale Law School, for instance, offers "Graduate

90 NORTHWESTERN PLAN 2008, http://www.law.northwestern.edu/difference/strategicplan.html, at 16. Last accessed 16 June 2009.

${ }^{91}$ Id.

${ }^{92} / d$.

93 Just to give an example, in the last three or four semesters, Fordham Law School offered the following: global/transnational courses: Advanced Legal Research: Transnational Practice, Advanced Legal Research: International and Comparative, Advanced Legal Research: International Trade Law, Civil Rights: 9/11 and NonCitizens, Comparative Constitutional Law, Doing Business in India, European and International Antitrust Law, Globalization of American Corporations: Tax and Regulatory Policy, Immigrants' Rights and Access to Justice, Immigration Law for Business Professionals, International and Comparative Patent Law, International Development Project: Millennium Development Goals, International Human Rights Scholarship, International Law of Development, International Litigation in U.S. Courts, International Cartel Enforcement, Introduction to Chinese Law, Islamic Law, Jewish Law, Law and Governance in Comparative Perspective, Law and Society in Japan, Law and Policy of Climate Change, Multinational Corporations, NAFTA, National Security Law, Professional Responsibility in Multinational Practice, Transnational Business \& Human Rights, and U.S. Foreign relations Law. See http://law.fordham.edu/registrar.htm. Last accessed 16 June 2009.

${ }^{94}$ For instance, the dean of Stanford Law School has noted the law school's intent to expand global course offerings, particularly to explore cross-border transactions between private parties such as international business and international trade, international procedure and arbitration, international tax, and international investment and development. AALS SURVEY, passim. 
Certificates of Concentrations" in International Development Studies, International Security Studies, African Studies, and Modern Middle Eastern Studies. ${ }^{95}$ Other law schools likewise offer a range of concentrations involving international and transnational law. ${ }^{96}$

While most of the expanded global law courses are upper-level electives, some U.S. law schools require their students to take such a course. Harvard Law School, for instance, imposes a mandatory requirement on its upper-level students; ${ }^{97}$ Michigan Law School requires its first year students to take a course in "Transnational Law" an organizing course to introduce students to basic concepts in transnational legal issues; ${ }^{98}$ Georgetown Law Center requires J.D. students to enroll in "Law in a Global Context," a one-credit weeklong required course that students take at the start of the second semester of the first year of law school. ${ }^{99}$ This program is premised on the notion that the "legal problems today's students must be prepared to face increasingly transcend national boundaries and involve more than one legal system." ${ }^{100}$

Other law schools provide first year electives on global law as one of several choices. ${ }^{101} \mathrm{~A}$ number of law schools encourage faculty members to incorporate global perspectives into

\footnotetext{
${ }^{95}$ See http://www.yale.edu/macmillan/grad_certificates.htm. Last accessed 16 June 2009.

${ }^{96}$ AALS SURVEY at 16.

97 See http://www.law.harvard.edu/academics/degrees/jd/pos/internationcomparativelaw/index.html. Last accessed 16 June 2009.

${ }^{98}$ See http://cgi2.www.law.umich.edu/_ClassSchedule/CourseList.asp. Last accessed 16 June 2009. This course is designed to "teach every student the minimum every lawyer should know about law beyond the domestic (American) orbit in order to be qualified for practice in an age in which virtually every area of law is being affected by international aspects. The basic idea is that every Michigan law student should take at least one serious look at law on the international level." http://cgi2.www.law.umich.edu/_ClassSchedule/aboutCourse.asp? crse_id=038594. Last accessed 16 June 2009. Michigan required course for upper level in Transnational Law. See http://cgi2.www.law.umich.edu/_ClassSchedule/CourseList.asp. Last accessed 16 June 2009. This course is designed to "teach every student the minimum every lawyer should know about law beyond the domestic (American) orbit in order to be qualified for practice in an age in which virtually every area of law is being affected by international aspects. The basic idea is that every Michigan law student should take at least one serious look at law on the international level." http://cgi2.www.law.umich.edu/_ClassSchedule/aboutCourse.asp? crse_id=038594. Last accessed 16 June 2009.

${ }^{99}$ See http://www.law.georgetown.edu/curriculum/jdprog.cfm\#First. Last accessed 16 June 2009.

${ }^{100}$ See http://www.law.georgetown.edu/documents/weekone2008.pdf. Last accessed 16 June 2009.

${ }^{101}$ Columbia Law School requires that first-year students select one of seven electives, including Lawyering Across Multiple Legal Orders. See http://www.law.columbia.edu/jd_applicants/curriculum/1l last accessed 16 June 2009; Minnesota Law School requires first-year students to select from a list of four electives, including International Law. See http://www.law.umn.edu/current/degreerequirements.html last accessed 16 June 2009. American University Washington College of Law and Yale Law School also offer electives to first-year students, which include international law courses.
} 
core first year doctrinal courses. ${ }^{102}$ At least one law school has provided stipends for faculty members to encourage them to develop such materials. ${ }^{103}$ The integration of more global perspectives into the first-year curriculum was the subject of at least one panel at the annual meeting of the Association of the American Law Schools (AALS). ${ }^{104}$

The globalization trend has also impacted offerings; there are now a number of international and transnational law clinics being offered at law schools around the country $_{1}^{105}$ such as the Walter Leitner International Human Rights Clinic at Fordham Law School. ${ }^{106}$

Study abroad opportunities for U.S. law students have also expanded exponentially in recent years. ${ }^{107}$ These include summer study abroad programs and semester study abroad opportunities. $^{108}$ The American Bar Association regulates these programs and has been supportive and now permits up to one-third of a student's J.D. program to be completed abroad. $^{109}$ A number of U.S. law schools have more recently begun to offer dual degree programs with foreign law schools ${ }^{110}$ as well as LL.M. degrees in foreign countries. ${ }^{111}$

\footnotetext{
${ }^{102}$ See, e.g., NORTHWESTERN'S PLAN 2008, http://www.law.northwestern.edu/difference/strategicplan.html, at 20. Last accessed 16 June 2009. As the then-Dean of NYU School of Law described the situation at his law school, "in the traditional canon of common law courses in the first year, at least two courses in each of the student sections now are taught from materials reworked to take account of globalization," an initiative he described as having as its purpose "introducing a perspective into the study of law ... that embraces the kaleidoscope nature of law formation, operation, and practice." John E. Sexton, supra note 59 at 199.

${ }^{103}$ See Michael P. Scharf, Internationalizing the Study of Law, 20 PenN State INTERnAtIonal Law Journal 29, 32 (2001).

${ }^{104}$ In 2005, the AALS annual meeting sponsored a Workshop on Integrating Transnational Perspectives into the First Year Curriculum.

${ }^{105}$ See AALS SURVEY at 21-23.

${ }^{106}$ See http://law.fordham.edu/ihtml/center3.ihtml?imac=1457. Last accessed 16 June 2009.

107 See, e.g.., James P. White, A Look at Legal Education: The Globalization of American Legal Education, 82 INDIANA LAW JOURNAL 1285, 1287 (noting that in 1975 there were five ABA-approved law schools offering a summer program abroad and that in 2006, 120 ABA-accredited law schools offered about 160 such programs).

${ }^{108}$ See http://www.abanet.org/legaled/studyabroad/abroad.html. Last accessed 16 June 2009.

${ }^{109}$ See id.

110 Examples include Fordham Law School's dual degree program with the University of Paris II, http://law.fordham.edu/ihtml/intl-2studyabroad_semester.ihtml?id=723; Harvard's joint J.D./LL.M. program with Cambridge University, http://www.law.harvard.edu/academics/degrees/special-programs/study-abroad/jointdegree-program.html; Columbia's dual degree programs with Paris I, the University of London, and the Institute for Law and Finance, http://www.law.columbia.edu/center_program/intl_progs/Double_degrees, Cornell's dual degree programs with Paris I, Sciences Po, and Humbolt, http://www.lawschool.cornell.edu/ international/study_abroad/international_dual_degrees/index.cfm; the University of Southern California's dual degree program with the London School of Economics, http://lawgip.usc.edu/studyabroad/jdlseinfo.cfm; and the
} 


\section{c) Experiential Learning}

The trend toward experiential learning in U.S. law schools has been ongoing for at least two decades. The goal of true experiential learning in the U.S. law school context nonetheless remains elusive. As Professor Erwin Chemerinsky has argued, "[ $t]$ he most important change that is needed in law school is to ensure that every student has a clinical experience or the equivalent ... Meaningful reform requires that law schools do far more to emulate the way medical schools train doctors."112

There are a number of law schools that have taken very seriously the notion that more experiential learning should be provided. The Carnegie Report itself pointed to experiential programs at New York University (NYU) and at the law school at City University of New York (CUNY) as offering exemplary experiential learning programs.

The CUNY curriculum integrates practical experience, professional responsibility, and lawyering skills with doctrinal study at every level, as described in the school's stated academic philosophy:

The basic premise of the Law School's program is that theory cannot be separated from practice, abstract knowledge of doctrine from practical skill, and understanding the professional role from professional experience. Our curriculum integrates practical experience, professional responsibility, and lawyering skills with doctrinal study at every level. Forming the core of our lawyering curriculum are the skills recognized by the profession in its 1992 report from the ABA Taskforce on Law Schools and the Profession (commonly known as the MacCrate Report) as essential to successful law practice-problem solving, legal analysis and reasoning, legal research, factual investigation, communication (legal writing, oral argument), counseling, negotiation, litigation and alternative dispute-resolution procedures, organization and management of legal work, and recognizing and resolving ethical dilemmas. ${ }^{113}$

University of Puerto Rico's dual degree program with the University of Barcelona, http://lspo.law.upr.edu/portal/page?_pageid=33,149936\&_dad=portal\&_schema=PORTAL. Last accessed 16 June 2009.

111 Examples include NYU's program at Singapore National University, http://www.law.nyu.edu/llmjsd/ Ilmsingapore/ index.htm and Northwestern's programs in Seoul, Madrid, and Tel Aviv. See http://www.law.northwestern.edu/graduate/llmexec/. Last accessed 16 June 2009.

${ }^{112}$ Erwin Chemerinsky, Rethinking Legal Education, 43 HARVARD CIVIL RIGHTS - CIVIL LIBERTIES LAW REVIEW 595, 595 (2008).

${ }^{113}$ http://www.law.cuny.edu/academics/AcademicPhilosophy.html. Last accessed 16 June 2009. 
NYU's commitment to situational learning is perhaps best summed up by John Sexton, then Dean of NUY School of Law, who opined that "[I]awyers don't encounter their clients in written opinions; they encounter them in situations." Sexton called for a "situation method" that would be used throughout law school - "and not simply for skills training but also to teach that a lawyer is a counselor, investigator, negotiator, advocate, and even moral authority; that the way she uses the law should take cognizance of the person's identity with whom she is dealing and the context in which she finds herself; and, most of all, that in real life a lawyer constantly finds herself in circumstances where she must serve society, even while serving her client. “114

In this vein, NYU offers a course called "Lawyering," which exposes all students in their first year to a range of lawyering skills, with intensive feedback and significant opportunities for self-reflection. "Lawyering is the study of law in use." ${ }^{115}$ In this course, [t]hrough a series of experiential, collaborative exercises, Lawyering students broaden and deepen their understanding of legal concepts and develop the analytic, interactive and interpretive skills that are integral to practice." The specific goals of the program are as follows: Learning through Experience; Learning Collaboratively; Learning through Critique; Learning through Recognizing and Understanding Difference; and Learning Beyond the Lawyering Program. In this required first-year course, "students work in role as attorneys to integrate sophisticated analysis of facts, careful research, thoughtful interpretation of law, sensitive elaboration of clients' desires, strategic analysis of lawyering interactions, and responsible consideration of the ethical requirements of the lawyer's role."116 There are seven exercises over the course of the two-semester course, each of which requires students to "analyze the components of a professional task, plan to undertake that task, implement their plans and engage in a structured critique of their work." ${ }^{117}$ Among other things, the exercises are designed "to instill life-long habits for learning from experience."

One additional law school that should be highlighted for its recent curricular reform is the law school at Washington and Lee University, which has transformed its traditional third year curriculum to a year-long program in Professionalism. The Professionalism program, which is in addition to the required second year course in professional responsibility, addresses the study of the law profession as a profession and explores the development of ethical judgment in context and in action. Students will be called upon in the course of Professionalism to exercise ethical judgment in simulations that are based on real-world

\footnotetext{
${ }^{114}$ Sexton, supra note 59 at 197.

${ }^{115}$ http://www.law.nyu.edu/academics/lawyeringprogram/mission/index.htm. Last accessed 16 June 2009.

${ }^{116} / d$.

${ }^{117}$ Id.

${ }^{118}$ /d.
} 
scenarios. The program will also address the development of professional identify beyond adherence to disciplinary ethics rules and managing one's life as a lawyer. In introducing the program, Dean Rod Smolla invokes the Chinese proverb: "Tell me, I will forget. Show me, I will remember. Involve me, I will understand."119 Dean Smolla states that the program's purpose "is to transform law school into a three year progression from purely academic study of law to the development of the lawyer's professional role as counselor and advocate in the highest ethical traditions of the profession. ${ }^{.120}$

Under this program, the third year will be entirely experiential, comprised of simulations and real client experiences that will lead to the development of professionalism and law practice skills. The program will also seek to develop in students all aspects of professionalism, including legal ethics, civility in practice, civic engagement, leadership, and pro bono service. ${ }^{121}$

Each semester of the third year will begin with a mandatory two-week immersion course in practice skills; one of these courses will focus on office and transactional practice skills, and the other will focus on litigation and other conflict resolution skills. In addition to these immersion courses, students will enroll in practicum courses that will include simulation and real client experiences (and which cover the spectrum of doctrinal work) and will be required to engage in extra-curricular law-related activities, which can include clinical work, externships, law review or moot court service, or student competitions. The program will involve practitioners and judges, known as "professors of practice," in the training of students throughout the course of this program. Throughout the year, students will be involved in "the full complement of professional activity that engages practicing lawyers as they apply legal theory and legal doctrines to the real-world issues of serving clients ethically and honorably within the highest traditions of the profession."122

The Professionalism program was founded on two driving ambitions. First, students ending their legal education should be given opportunities to express professional judgment in a variety of contexts. The "purposeful expression of considered judgment and counsel to solve client problems will receive greater attention." Second, "a third year law student should be expected to reflect more systematically on what it means to live one's life in the law. Students should recurrently consider and receive guidance on the admirable qualities, dispositions, attitudes, concerns, and habits - moral and intellectual -

\footnotetext{
${ }^{119}$ http://law.wlu.edu/thirdyear/. Last accessed 16 June 2009.

${ }^{120} / d$.

${ }^{121} / d$.

${ }^{122} / d$.
} 
of good lawyers.... In short, professional values in the best sense, not just competence, should be inculcated and transmitted as out students move toward practice."123

But experiential learning is a part of virtually every law school curriculum, although the focus and intensity of skills-based learning vary somewhat dramatically among schools. In response to a survey, most law schools indicated that law schools are doing much more than offer the traditional legal research and writing courses; most law schools have either expanded their legal research and writing courses by enhancing the number of credits awarded or by introducing additional skills in those courses, or in newly-created courses. ${ }^{124}$ The most common responses indicate that these courses include a broader set of "lawyering" skills (such as client interviewing and counseling and negotiation), the integration of skills into core doctrinal courses, the addition of an ethics and/or professionalism component into first year studies. ${ }^{125}$

What is more, the law schools that offer rigorous skills training vary enormously as judged by virtually any criteria. What follows are some examples of law school skills courses offering experiential learning:

Liberty Law School, a new law school that received students for the first time in August 2004, adopted a skills program that consists of six semesters of stand-alone courses called Lawyering Skills (Lawyering Skills I - VI) comprising a total of fourteen credit hours. These courses include a thread in Adjudication and in Planning, each of which runs throughout the program. ${ }^{126}$

William and Mary has developed a new two-year legal skills program that is designed to help students develop the skills lawyers need in practice through simulated cases. In this program, students simulate client interviews, negotiations, discovery practice, and other

${ }^{123}$ Id.

${ }^{124}$ See id.. At least some respondents also indicated that they have enhanced research training in the first year by including members of the professional library staff rather than relying exclusively on legal research and writing instructors for research training.

${ }^{125}$ Beyond the classroom, a number of states permit admission to the bar after a legal education secured through apprenticeships rather than attendance at law school, a return to earlier days and an implicit recognition of the value of learning by doing. ${ }^{125}$ These states are California, Maine, New York, Vermont, Virginia, Washington, and Wyoming. See G. Jeffrey MacDonald, The Self-Made Lawyer, CHRISTIAN SCIENCE MONITOR, 3 June, 2003, at 13. Delaware requires bar applicants to "perform an aggregated full-time service of at least five months in a law office, as a judicial law clerk, or working for various federal, state, or legal services agencies prior to their admission to the state bar." DelawARe SuPREME Court RePORTS. 52(8). During this time they must complete a list of thirty tasks. Id.

${ }^{126}$ Matthew D. Staver, Liberty University's Lawyering Skills Program: Integrating Legal Theory in a PracticeOriented Curriculum, 39 UNIVERSITY OF TOLEDO LAW REVIEW 383, 386 - 88 (2008). 
important skills that are not typically introduced in the first year legal research and writing courses. $^{127}$

Gonzaga Law School has introduced a Skills and Professionalism Curriculum that requires students to take skills and professionalism courses in all three years of law school. This was achieved through the addition of a 2-credit Litigation Skills and Professionalism Lab in the first semester; a 2-credit Transactional Skills and Professionalism lab in the second semester; a 3-credit Perspective on the Law course; and a required clinic or externship in the third year. These new courses are in addition to the two-part, four-credit course in Legal Research and Writing in the first year. ${ }^{128}$

Case Western Reserve University School of Law initiated a CaseArc Integrated Lawyering Skills Program. This program is essentially a re-design of the law school's more traditional legal analysis, research, and writing, and lawyering skills program into a more fully integrated and sequenced curriculum which extends over all three years of law school. This program consists of an extensive Introduction/Orientation program, four required courses, and a capstone course, which is either a real client clinic, an externship, or a lab. Team teaching integrates legal theory and doctrine, lawyering skills, and the professional role. Doctrinal subjects are linked with legal analysis, research, writing, and problemsolving. Simulations are used to teach fundamental skills including interviewing, counseling, negotiation, and oral presentation. The underlying principles of this program are identified as follows: (1) exposure of all students to fundamental skills (defined as fact investigation including document review, client interviewing, client counseling, legal research tools and methods, legal analysis, legal problem solving and strategic thinking, legal writing in litigation and non-litigation contexts, oral presentation in different contexts, including objective, persuasive, formal and informal, negotiation and other ADR techniques, the transactional planning process, and recognizing and resolving ethical dilemmas); (2) integration of skills and substance; (3) graduated complexity; (4) repetition; and (5) collaboration and coordination. ${ }^{129}$

The University of Dayton law school has developed a Lawyer as Problem Solver program, which builds on the "traditional 'counselor at law' concept" to "help clients solve complex problems and make appropriate choices," by trying to train students to "act with sound

\footnotetext{
${ }^{127}$ http://law.wm.edu/academics/programs/jd/requirements/legalskills/curriculardetails/index.php. Last accessed 16 June 2009.

128 http://www.law.gonzaga.edu/academic+program/academics/curriculum/legal_research_writing/default.asp. Last accessed 16 June 2009.

${ }^{129}$ See Kenneth R. Margolis, Turning Law Students into Lawyers, THE COMPLETE LAWYER, VoL. 3 No. 5 (14 September 2007).
} 
judgment and common sense." ${ }^{130}$ This program includes skills integration throughout the curriculum, including required externship, small-enrollment capstone or clinical course, and introductory dispute resolution course for every student in addition to traditional skills offerings. ${ }^{131}$

Drake University School of Law has launched its First-Year Trial Practicum (FYTP) in which all first year students devote a week to observing and discussing an actual jury trial - from jury selection to verdict. FYTP is the first component of the law school's experiential education pyramid: observation - simulation - participation. Students meet in small groups to discuss the day's proceedings and have the opportunity to meet with the judge and the lawyers. ${ }^{132}$

The University of Northwestern has undertaken a comprehensive study and amendment of its curriculum in what it calls its Plan 2008. Northwestern's Plan 2008 discusses the need to enhance experiential learning by including more in-class simulations, providing concrete examples from actual practice, and intertwining clinical practices resources with substantive first year courses. Among other things, Northwestern University School of Law's Plan 2008 does the following:

- Identifies a discrete set of abilities and traits that law graduates need to help ensure their career success. These "foundational competencies" are organized into related groups - legal analysis and understanding, communication skills, business skills, relationship and leadership abilities, management skills, and personal traits.

- Proposes to establish intensive third year experience which would allow an opportunity for semester-long faculty-supervised, full-time experience within or outside the law school in which they can put into practice their prior learning. These can be clinical practice sections, practicum or internships, intensive academic experiences working on research with individual faculty members or outside apprenticeships, including at foreign law firms.

- Recognizes the importance of giving students the opportunity "to learn through supervised experience, to concretize more abstract ideas in the process, and to sensitize students to the needs of clients with backgrounds and aspirations different from those which students have previously encountered." ${ }^{133}$ Plan 2008 calls for "more

\footnotetext{
${ }^{130} \mathrm{http} / / /$ law.udayton.edu/NR/exeres/A90D0C0C-C138-49E1-8D73-3A791AA1BECB.htm. Last accessed 16 June 2009.

${ }^{131} / d$.

${ }^{132}$ http://www.law.drake.edu/academics/?pagelD=trialPracticum. Last accessed 16 June 2009.

${ }^{133}$ http://www.law.northwestern.edu/difference/strategicplan.html. Last accessed 16 June 2009.
} 
integration of concrete examples, simulations, and case studies with traditional theoretical discussion."134

Southwestern law school expanded its first-year legal research and writing program and created a new program called LAWS (Legal Analysis, Writing and Skills). This six-credit course (double the credits that were awarded under its pre-existing legal research and writing program) provides more detailed instruction in legal methods, legal reasoning, client and witness interviewing, and appellate advocacy. The LAWS program also addresses issues relating to professionalism and the practice of law. ${ }^{135}$

At the University of Washington, business law courses focus on problem solving through a case problem and use writing as an important tool for lawyers. ${ }^{136}$ In addition, the law school provides a Foundation for Legal Study Orientation Program which traces the trajectory of a case from start to finish, using simulations and demonstrations to supplement lectures. ${ }^{137}$

University of Detroit-Mercy developed a new approach to teaching that emphasizes solving legal problems, building a bridge to practice, and learning to practice. ${ }^{138}$

At the University of Connecticut, the course Lawyering in the Community: Experiential Learning in the First Year as a Gateway to Pro Bono integrates a real life legal experience into the first year legal skills. Numerous models have been employed - having the entire class work on a single pro bono project, offering multiple outside projects from which students can choose, or a combination of both. ${ }^{139}$

The University of Washington offers capstone course in legal analysis, writing, and research during the third quarter of the first year. Students select an area of interest and complete research and writing projects in that area. The goal of this course is to integrate skillsbased knowledge and information-based knowledge into a unified whole. ${ }^{140}$

\footnotetext{
${ }^{134} / d$.

${ }^{135}$ See http://www.swlaw.edu/academics/jd/newcurriculum1. Last accessed 16 June 2009.

136 See legal Education at the Crossroads - IDEAS to Accomplishments: Sharing NeW IDEAS for INTegrated CURRICULUM, 9-12, available at http://bestpracticeslegaled.files.wordpress.com/2008/09/crossroads matlsonline.pdf Last accessed 16 June 2009. (“CROSSROADS”)

${ }^{137}$ Id.

${ }^{138}$ See http://www.law.udmercy.edu/academics/index.php. Last accessed 16 June 2009.

${ }^{139}$ See CROSSROADS at 49-52.

${ }^{140}$ See CROSSROADS at 21-24.
} 
Washington and Lee has entirely restructured its third year program to include intensive two-week courses in Transactional Practice and Dispute Resolution Practice, which emphasize litigation, mediation, arbitration, and negotiation skills. The revision aims to transform the third year into a "year of professional development through simulated actual practice experiences." 141

Southwestern Law School now has a one-week January intersession program which will feature more than ten innovative courses that are more suited to short-term, intensive treatment than to a traditional semester. Offerings include Legal Spanish for International Practice and The Art of Persuasion. ${ }^{142}$ The law school also offers capstone courses that provide advanced study with special emphasis on applying theory to practice and on professionalism. Skills include advocacy, alternative dispute resolution, and a variety of transactional skills. ${ }^{143}$

Vanderbilt Law School has a third-year curriculum that includes Civil Litigation Capstone Seminar, a year-long seven-unit seminar for students interested in professional careers in the civil justice system. ${ }^{144}$

The University of Minnesota is planning a variety of new courses being rolled out over a number of years to better prepare students for law practice. New classes include intensive training in statutory interpretation integrated into a brief-writing program; "The Work of the Lawyer'" introducing students to the practice of law and its ethical and theoretical underpinnings; and "Perspectives on the Law," a team-taught class exposing students to several different perspectives on such legal issues as law and economics and critical race theory. ${ }^{145}$

The University of New Mexico School of Law offers a practicum course designed to develop in first-year students practical lawyering skills and ethical and professional responsibility. Hypothetical exercises are built around a particular substantive law foundation to encourage students to think in practical ways about client representation. Exercises include a mock client interview, a draft letter to the client, a draft letter from the client to a third party, an analysis of a factual record. The program also includes presentations by lawyers working in various fields. ${ }^{146}$

\footnotetext{
${ }^{141}$ See http://www.law.wlu.edu/thirdyear/. Last accessed 16 June 2009.

${ }^{142}$ See http://www.swlaw.edu/academics/jd/newcurriculum2. Last accessed 16 June 2009.

${ }^{143}$ Id.

144 See http://law.vanderbilt.edu/academics/curriculum/elective-courses/civil-litigation-capstone-seminar/index. aspx. Last accessed 16 June 2009.

${ }^{145}$ See http://www.law.umn.edu/prospective/curriculum.html. Last accessed 16 June 2009.

${ }^{146}$ See CrossroAds at 5-8.
} 
The law school at California Western has developed a STEPPS Program: Skills Training for Ethical and Preventive Practice and Career Satisfaction. The program includes lectures, readings, case handling and management, office meetings, skills practice (including drafting), and detailed and specific feedback. ${ }^{147}$

Chicago-Kent College of Law's Center for Access to Justice and Technology includes courses in litigation technology and other courses to help students keep pace with emerging technologies. ${ }^{148}$

DePaul University College of Law's Litigation Lab enables upper-class students to have interchanges with lawyers about real cases. ${ }^{149}$

Touro College Jacob B. Fuchsberg Law Center's Public Advocacy Center houses agencies in areas such as housing, immigration, domestic violence, and civil rights, each of which uses Touro students in advocacy services, research work, and client relations. ${ }^{150}$

At the University of Detroit, Mercy School of Law, students may take up to one-third of their credits toward the J.D. degree in Spanish. ${ }^{151}$

Clinical legal education also continues to expand. More and more law schools offer more and more varied clinics. In addition to more traditional clinics, clinical offerings now include intellectual property, elder law, human rights, immigration, fair housing, child welfare, family mediation, domestic violence, environmental litigation, international human rights, securities arbitration, disability law, post-conviction, and health law. ${ }^{152}$

d) More Integration of Theory and Practical Skills

Traditionally, the teaching of legal skills and the teaching of doctrine have been accomplished separately, with little interaction between the two sets of classes (or faculty). Recently, and as a corollary of the renewed emphasis on skills-based learning, a number of law schools have begun to do more to integrate theory- and skills-based education. For instance, the CaseArc Program at Case Western Reserve University School

\footnotetext{
${ }^{147}$ See CROSSROADS at 72.

${ }^{148}$ http://www.kentlaw.edu/cajt/. Last accessed 16 June 2009.

${ }^{149}$ http://www.law.depaul.edu/programs/professional_skills/lit_lab.asp. Last accessed 16 June 2009.

${ }^{150} \mathrm{http}: / /$ www.tourolaw.edu/pac/index.asp. Last accessed 16 June 2009.

151 http://www.martindale.com/xp/legal/Professional_Resources/Law_Schools/schl0215.xml. Last accessed 16 June 2009.

${ }^{152}$ See AALS SURVEY, passim.
} 
of Law seeks to integrate theoretical and practice-oriented training, and has been described as follows:

CaseArc courses ... are integrated with or "inked" to a substantive area of law that students are studying at the same time or in which they have an interest. We believe this will enhance the learning of the subject matter and doctrine as well as the particular lawyering skill under consideration because each will be informed by the other, giving added relevance to both.... This integration permits us to develop rich, content-based and life-like situations for students to grapple with in their writing projects and simulations. It also fosters a deeper understanding of the theory and doctrine of the substantive area. $^{153}$

At the University of New Mexico, skills and professionalism training have been added to most business and tax courses. Desired outcomes include learning how to draft contracts, negotiate deals, understand business objectives of clients, understand how laws and markets interact, effectively navigate federal, tribal, and state regulatory regimes. This program is based on the belief that "substantive black-letter law and theoretical approaches to learning are not mutually exclusive, but rather reinforce one another. Both are critical components of training the complete business lawyer." ${ }^{154}$

e) Teaching Professionalism and Ethics more Pervasively (and Experientially)

Warren E. Burger, then Chief Justice of the United States, once remarked as follows:

[P]rofessional ethics must have far greater attention from the profession. This should begin on the first hour of the first day in the law school. American law schools perform very well the task of training in the law and in legal analysis. But a system of legal education that teaches lawyers the skills of legal thinking and analysis yet fails to teach them how to act with civility ad according to high professional standards with a commitment to human values, has failed to perform its mission. ${ }^{155}$

A number of schools have begun to take the teaching of lawyer ethics and professional responsibility more seriously. For instance, the law school at William and Mary emphasizes

\footnotetext{
153 Kenneth R. Margolis, Turning Law Students into Lawyers, THE COMPLETE LAWYER, Vol. 3 No. 5 at 4-5 (14 September 2007).

${ }^{154}$ http://lawschool.unm.edu/clinic/business-tax-law/index.php. Last accessed 16 June 2009. See also CROSSROADS at $5-8$.

${ }^{155}$ Warren E. Burger, The Role of Lawyers Today, 59 NotRE DAME LAW REVIEW 1, 3, 5 (1983).
} 
the ethical practice of law through the philosophy of the "citizen lawyer," embodied in "the Jeffersonian ideal of the lawyer as skilled advocate and devoted public servant."156 The law school promises its students that "from the very first day, you'll be putting ethical lawyering skills to practice in a supportive academic setting." 157 The Skills and Professionalism curriculum at Gonzaga Law School includes Professionalism Labs in both litigation skills and transactional skills. ${ }^{158}$ Students at Northeastern University School of Law take a first year course called Legal Skills in Social Context which, among other things, explores law in its social context and requires pro bono work. ${ }^{159}$ At Washington University, first year students go on a field trip to criminal court to reinforce the humanity of the parties. ${ }^{160}$

\section{f) Enhanced Feedback}

Law schools in the U.S. typically provide feedback to students in the form of a single grade at the end of each semester based on a single examination or paper. This is not always the case, of course; in legal writing and other skills courses, there is more systematic and personalized feedback. Other courses may require students to submit short papers along the way, but this has been the exception to the norm.

Some law schools have begun to focus more on the frequency and quality of feedback that is provided to students. Northwestern's Plan 2008, for instance, calls for feedback and evaluations during and at the end of each course to allow students to learn from the feedback and adjust their learning techniques accordingly. ${ }^{161}$ Case Western Reserve's CaseArc program has "developed evaluative tools which are designed to give qualitative formative feedback to ... students while they can still improve." ${ }^{162}$ For the most part, however, law school feedback continues to be evaluative only, and comes only at the end of the semester.

\footnotetext{
${ }^{156}$ http://law.wm.edu/academics/. Last accessed 16 June 2009.

${ }^{157}$ Id.

158 See http://www.law.gonzaga.edu/News-and-Events/newsdetail.asp?EventID=4487\&DepartmentID=15 last accessed 16 June 2009.

${ }^{159}$ See http://www.northeastern.edu/law/academics/curriculum/lssc/ last accessed 16 June 2009.

${ }^{160}$ See Emily Hughes, Taking First-Year Students to Court: Disorienting Moments as Catalysts for Change, 28 WASHINGTON UNIVERSITY JOURNAL OF LAW \& POLICY 11 (2008).

161 See http://www.law.northwestern.edu/difference/NorthwesternLawPlan2008.pdf. Last accessed 16 June 2009.

${ }^{162}$ Kenneth R. Margolis, Turning Law Students into Lawyers, THE COMPLETE LAWYER, Vol. 3 No. 5 at 7 (14 September 2007).
} 


\section{g) Teaching the Teachers}

There have been a few efforts designed to help law school instructors engage in effective teaching methods and educational theory. Perhaps the most established of these initiatives is the Institute for Law Teaching at Gonzaga University School of Law, which was created in 1991. This Institute focuses on effective teaching and learning in law school via teaching conferences and workshops, publishing articles, and posting on-line resources for teachers. ${ }^{163}$ Georgetown Law Center offers a teacher training workshops over the summer directed toward mid-level clinical professors. ${ }^{164}$ The law schools in the District of Columbia have begun a "Rounds About Teaching" program in which law professors meet in workshop-style format to discuss teaching techniques and ways to implement Best Practices and Carnegie Report recommendations. ${ }^{165}$ The Center for Computer-Assisted Legal Instruction (CALI) is non-profit consortium of law schools that provides legal education resources over the internet. ${ }^{166}$

\section{Conclusions}

And now for some modest conclusions.

First, the recent and significant changes in U.S. legal education will continue, but they are not likely to be transformative. In other words, the model of legal education that has been in place for the last century will continue - albeit with updates and improvements.

Second, the changes that we are likely to see are likely to follow the pattern of recent years. More and more law schools will offer opportunities for students to specialize. This will include changes to the first year curriculum, including more opportunities for such students to choose from among a select offering of electives; more and more law schools will provide global opportunities, whether they are offered on campus or around the world; and law schools will expand their efforts to provide experiential learning opportunities for their students. These efforts will be moderated by cost and other constraints, but law schools will be aware of the value of and demand for skills-based learning that helps bridge the gap between school and practice. I am skeptical that many schools will improve substantially the genuine integration of doctrinal and skills-based

\footnotetext{
163 See http://www.law.gonzaga.edu/About-Gonzaga-Law/Institute-for-Law-School-Teaching/default.asp. Last accessed 16 June 2009.

${ }^{164}$ See CROSSROADS 1-3.

${ }^{165}$ See Crossroads at 33.

${ }^{166}$ See www.cali.org. Last accessed 16 June 2009.
} 
teaching, in part because there remains at most law schools a separation between those faculty members who teach substantive law and skills.

Third, law schools should respond more reflectively to technological changes than they have been. Lawyers will be making greater use of technology in the future, and there will be increasing demand for law schools to keep pace.

Finally, the recent burgeoning of online J.D. programs that we have seen in recent years ${ }^{167}$ is not likely to become a major trend in U.S. legal education. Although they have sparked some interest among students and others, they are at the opposite end of the spectrum in terms of demands for changes to legal education. Nor do I foresee that the American Bar Association will view these laws schools as substitutes for mainstream law schools.

\footnotetext{
${ }^{167}$ These include Concord Law School (http://www.concordlawschool.edu/index.asp?source $=106813 \& v e=60120 \&$ phid=11\&ysmwa=[ysmwa]\&gclid=CKy9kP6hh5sCFQpgswodsyK5ow), Northwestern California University (http://www.nwculaw.edu/cgi-bin/nwcu/index.html), and West Coast School of Law (http://www.westcsl.com/) Last accessed 16 June 2009.
} 